\title{
INCLUSIVE METHODOLOGIES FROM THE TEACHING PERSPECTIVE FOR IMPROVING PERFORMANCE IN UNIVERSITY STUDENTS WITH DISABILITIES
}

\author{
Alejandro Lorenzo-Lledó $(\mathbb{D})$, Gonzalo Lorenzo $(\mathbb{D})$, Asunción Lledó(iD, Elena Pérez-Vázquez (iD) \\ Department of Development Psychology and Teaching, University of Alicante (Spain) \\ alejandrolorenzo@ua.es,.glledo@ua.es,asuncion.lledo@ua.es,elena.pv@ua.es
}

Received December 2019

Accepted December 2019

\begin{abstract}
One of the challenges proposed by the European framework for higher education has been to develop a quality and accessible university education in order to reduce situations of exclusion of disabled students. In this sense, it is essential to reduce the existing gap in the academic performance of this group with respect to other students. The general objective of this study has been to analyze the application of inclusive methodologies in university students with disabilities from a teaching perspective. The adopted methodology was non-experimental quantitative with a sample of 313 teachers from the University of Alicante who have taught students with disabilities and who responded to a questionnaire designed ad hoc of 51 items. The results obtained show that teachers frequently use visual aids and use the same materials both in theory and in practice. Concerning perceptions, teachers consider that students with disabilities should acquire the same skills as the rest of their classmates and it was not difficult for them to teach them. Furthermore, the results showed significant differences in perceptions according to the professional category and the branch of knowledge of the teachers. From the aforementioned, it can be concluded that, although positive changes are perceived in teaching methodologies, it is necessary to continue making progress in improving teaching practice and the quality of education that facilitates the conditions for the academic performance of people with disabilities in Spanish universities.
\end{abstract}

Keywords - Disability, Inclusive education, Academic achievement, Higher education, Teaching methodologies.

\section{To cite this article:}

Lorenzo-Lledó, A., Gonzalo Lorenzo, G., Lledó, A., \& Pérez-Vázquez, E. (2020). Inclusive methodologies from the teaching perspective for improving performance in university students with disabilities. Journal of Technology and Science Education, 10(1), 127-141. https://doi.org/10.3926/jotse.887

\section{Introduction}

One of the challenges proposed by the European framework for higher education has been to develop a higher education of quality, excellence and accessible to all in accordance with the demands of the current society. In recent years, this approach has reduced the exclusion of disabled students. The World Declaration on Higher Education in the 21st Century already mentions in article 3, letter d, as one of the 
principles of action, facilitating access to higher education for specific groups such as people with disabilities, considered individually as a group (UNESCO, 1998).

The objective that university institutions are assuming to achieve university educational excellence entails assuming new educational paradigms that increase access to higher education. UNESCO at the World Conference on Higher Education: The New Dynamics of Higher Education and Research for Social Change and Development in 2009 and in the Training Tools for Curriculum Development. Reaching out to all Learners: A Resource Pack Supporting Inclusive Education of 2016, advocates achieving the goals of equity, relevance and quality and elevating inclusive education as a right of all people and at all stages of education. All of this was preceded by a series of international initiatives such as the 2007 United Nations International Convention on the Rights of Persons with Disabilities or the Incheon Declaration from the Education Framework 2030 of 2015, which aims to promote inclusive and equitable quality education and promote lifelong learning opportunities for all. From this perspective, inclusion and equity in education is the cornerstone of transformative education, focusing efforts on access, equity, quality and learning outcomes, as well as teacher training and curricula.

Nevertheless, if we bring up academic performance, it should be noted that access to international data on the academic achievement of students with special educational needs is very limited (Martin \& Kang, 2018) and is mainly identified at lower educational stages. Different researches (Alper \& Ryndak, 1992; Scruggs \& Mastropieri, 1996, 2004; Morgan, Farkas \& Wu, 2011) show the great gap in the academic achievements of this group with respect to the rest of students, being even greater in higher education (Nelson, Benner, Lane \& Smith, 2004). In general, the academic performance of students can be understood as a construction related to many learning domains (Guskey, 2013). In this sense, the concept of academic achievement is associated with what we know, do, and care about, and may change in meaning as students' progress through different educational levels (Hattie \& Anderman, 2012).

In the Spanish university context, as can be seen in the Disability Care Guide 2018, published by the Universia Foundation, a total of 22190 people with disabilities study at Spanish universities, being their presence greater in face-to-face than in non-face-to-face universities. Given the presence of this group in classrooms, the need for universities to adopt a new educational paradigm of inclusive orientation is unquestionable, since success in academic performance does not depend exclusively on the student himself (Moriña, 2019), but also on the resources, materials and personnel that universities have at their disposal to serve students with disabilities and provide them with a quality education (Thomas, 2016). Deepening in the Spanish university context, the Organic Law 4/2007, of April 12, bets for the inclusion of people with disabilities in the university and establishes in order to make effective the equality of opportunities the design of accessible spaces, to apply the principles of accessibility and design for all. This should make teachers rethink the methodologies used in university classrooms, since, despite this inclusive approach, the reality is still far from what university regulations aim to achieve (Booth, 2006; Díaz \& Funes, 2016).

Research has identified barriers to the academic success of people with disabilities at university (Díez \& Sánchez, 2015; González-Cortés \& Roses-Campos, 2016; Moriña, Cortés \& Molina, 2015). Among these barriers, it is notable the use of methodologies that do not allow students to participate fully in the teaching-learning process (Castellana \& Sala, 2006). The use of a methodology based on the master class, which has been so present in the university context (Marcelo \& Yot, 2010), makes it difficult for people with disabilities to follow the rhythm of the class on a regular basis (Borland \& James, 1999). Therefore, in order to overcome these difficulties, it is convenient to opt for inclusive tools and strategies that promote understanding of the content (Moriña-Diez, López, Melero, Cortés \& Molina, 2013) and to delimit the barriers that university students face (spaces, resources, methodologies...) to convert university classrooms into inclusive and non-exclusive classrooms (Sandoval, Simón \& Márquez, 2019). In this line, the proposals coming from the educational paradigm of the Universal Design for Learning (DUA), developed by the Center for Applied Special Technology. 
The main aim of this research is to analyze the application of methodologies in university students with disabilities from the perspective of the teacher. The following specific objectives underlie this general purpose:

- To identify the degree of application of inclusive methodologies by teachers in university students with disabilities.

- To know the teaching perceptions about the application of inclusive methodologies in university students with disabilities.

- To identify possible significant differences in teaching perceptions on the application of inclusive methodologies in university students with disabilities according to the professional category and the branch of knowledge of the teaching staff.

\section{Method}

The study adopted a non-experimental quantitative approach, characterized by the determination to quantify phenomena or opinions through numerical data without manipulating independent variables (Cohen \& Manion, 1990; Latorre, Del Rincón \& Arnal, 2005). It is also a comparative-causal study (Bisquerra, 2014) since, in addition to offering descriptive information on the quantified variables, the possible significant differences according to the compared groups have been analyzed, trying to establish causal relationships. On the other hand, when data collection is carried out at a given time, it is also a transversal study (León \& Montero, 2002).

\subsection{Participants}

This research has been developed in a specific context, the University of Alicante, with a sample of 313 teachers who have taught students with disabilities. All participants received an information letter explaining the objectives of the research. In addition, they had to give their consent for the treatment of the information. The research was totally anonymous and those who did not want to participate returned the questionnaire without filling it in. Access to the sample was carried out according to the availability of access to the teaching staff, so, following Albert (2007), an accidental or causal non-probabilistic sampling technique was used. Of the participating teachers, $64.2 \%$ were men and $35.8 \%$ were women. The years of teaching oscillate in a wide range of between one and forty years of teaching experience, with a mean of 14.81 and a standard deviation of 8.28. With regard to the professional category, Table 1 below describes the sample according to this variable.

\begin{tabular}{|l|r|r|}
\hline Professional category & Frequency & Percentage \\
\hline Full Professor & 39 & 1.5 \\
\hline Senior Lecturer & 96 & 30.7 \\
\hline University School Professor & 4 & 1.3 \\
\hline University School Holder & 31 & 9.9 \\
\hline Lecturer & 17 & 5.4 \\
\hline Assistant doctor & 18 & 5.8 \\
\hline Tutor & 16 & 5.1 \\
\hline $\begin{array}{l}\text { Others (scholarship holders, teaching fellow, } \\
\text { collaborators) }\end{array}$ & 92 & 29.4 \\
\hline Total & 313 & 100.0 \\
\hline
\end{tabular}

Table 1. Sample participant by professional category

Regarding the field of knowledge, as can be observed in Table 2, the highest percentage of professors (39.0\%) belongs to the field of Social and Legal Sciences. 


\begin{tabular}{|l|r|r|}
\hline Field of Knowledge to which it belongs & Frequency & Percentage \\
\hline Humanities & 61 & 19.5 \\
\hline Health Sciences & 16 & 5.1 \\
\hline Social and Legal Sciences & 122 & 39.0 \\
\hline Experimental Sciences & 37 & 11.8 \\
\hline Engineering and Technology & 77 & 24.6 \\
\hline Total & 313 & 100.0 \\
\hline
\end{tabular}

Table 2. Sample participant by field of knowledge

Regarding the degrees taught by the participating teachers, Table 3 shows the data in their different combinations.

\begin{tabular}{|l|r|r|}
\hline Degrees in which teaching is given & Frequency & Percentage \\
\hline Grade & 119 & 38.0 \\
\hline Master's degree & 5 & 1.6 \\
\hline Doctorate & 1 & 0.3 \\
\hline Other & 4 & 1.3 \\
\hline Grade and master's degree & 95 & 30.4 \\
\hline Grade and Doctorate & 2 & .6 \\
\hline Grade and Others & 16 & 5.1 \\
\hline Master's degree and Doctorate & 3 & 1.0 \\
\hline Grade, Master's degree and Doctorate & 52 & 16.6 \\
\hline Grade, Master's degree and Others & 10 & 3.2 \\
\hline Grade, Master's degree, Doctorate and Others & 6 & 1.9 \\
\hline Total & 313 & 100.0 \\
\hline
\end{tabular}

Table 3. Degrees taught by the participating sample

The participating teachers had a few students with disabilities between one and thirty-two, with a mean of 2.98 and a standard deviation of 3.23. The type of disability in this group of students was diverse, with visual disability (15.7\%), physical disability $(11.5 \%)$, hearing disability $(3.2 \%)$ and a percentage of teachers of $7.7 \%$ who had students with physical and visual disabilities and $4.2 \%$ with physical, visual and hearing disabilities, among the highest percentages. No more than $1 \%$ of teachers have had students with Asperger's syndrome or with language problems. As the most significant percentage, $29.4 \%$ of the professors were informed of the disability by the student himself, while $5.4 \%$ were informed by the CAE, $13.1 \%$ by both the student and the CAE and $9.6 \%$ by teachers were not informed by anyone. With regards to knowledge of the existence at the University of a care and support service for students with disabilities, $61.3 \%$ of the teaching staff were aware of this. On the other hand, a large percentage of the participating lecturers $(74.4 \%)$ did not know that in the university entrance examinations some aspect was regulated regarding students with disabilities.

\subsection{Instrument}

After reviewing the literature on the topic under study, and with the purpose of satisfying the aims proposed, the ADU questionnaire was designed ad hoc (Students with Disabilities in the University), which in its first version consisted of 54 items. This questionnaire was elaborated within the Project "European Space for Higher Education, Diversity and Teaching Excellence: Analysis and proposals on indicators and inclusive practices in university teaching methodologies" and was subsequently submitted to the opinion of experts, who, following what was said by authors such as Sánchez (1994) and Barroso and Cabero (2010), is the most appropriate mechanism for obtaining the validity of an instrument's content. 
In order to quantify the assessments conducted by ten experts in the field, the procedure for calculating the validity of content proposed by Lawshe (1975) through the content validity index (IVC) was used. As a result of the expert opinion, three items of the questionnaire were irrelevant and were eliminated, leaving a version of the 51-item questionnaire with a DVI of 1 and, therefore, with good content validity. Furthermore, with the version of the questionnaire obtained after the opinion of experts, a pilot test was carried out with 14 teachers, from which the writing of some items was specified, obtaining the final version of the questionnaire. In the same way, in order to check the reliability of the questionnaire, the internal consistency coefficient Alfa de Cronbach was calculated, obtaining 0.85. This data shows, following George and Mallery (2003), that the questionnaire designed has a good internal consistency index.

The final version of the 51-item ADU questionnaire is structured around three well-differentiated parts:

- First part: the variables that identify the sample (items 1 to 11 ).

- Second part: the degree of application of inclusive methodologies in university students with disabilities (items 12 to 21). A Likert scale with 5 values is used, where 1 is not frequent, 2 is infrequent, 3 is moderately frequent, 4 is quite frequent and 5 is totally frequent.

- Third part: teaching perceptions on the application of inclusive methodologies in university students with disabilities (items 22 to 51). This part is also composed of three dimensions:

- Training for the application of inclusive methodologies (items 22 to 29).

- Difficulty in the application of inclusive methodologies (items 30 to 43).

- Accessibility for the application of inclusive methodologies (items 44 to 51).

All the items of this third part are also of closed response type Likert with 5 values $(1=$ very disagree; $2=$ disagree; $3=$ not agree, not disagree; $4=$ agreement; $5=$ very agree).

\subsection{Procedure}

The questionnaire was completed on paper during the academic year 2018/2019 and for its distribution among the lecturers of the different faculties and fields of knowledge of the University of Alicante, the internal mail of the University of Alicante was used. The questionnaire was accompanied by a presentation letter of the research and instructions for answering the questions individually. The teachers who agreed to participate returned the completed questionnaire to the authors of the research also by internal mail.

\subsection{Data Analysis}

The data were processed using the SPSS statistical package for Windows (Statistical Package for Social Sciences) version 21. The data analysis includes descriptive statistics, with the frequencies, percentages, mean and typical deviations corresponding to the answers given to the questionnaire. Furthermore, nonparametric tests were used to carry out a comparative analysis of possible significant differences based on the selected variables.

\section{Results}

In the following lines, the results of the study are presented, which are grouped according to the quantified variables.

\subsection{Level of Application of Inclusive Methodologies in University Students with Disabilities}

Table 4 presents the results of the descriptive statistics referring to the mean and typical deviations on the frequency of application of inclusive methodologies by teachers with their university students with disabilities as a function of the five response categories contemplated. 


\begin{tabular}{|c|c|c|c|c|c|}
\hline Ítems & $\mathbf{N}$ & Minimum & Maximum & Average & DT \\
\hline $\begin{array}{l}\text { 12. I facilitate the notes and the materials of the subject } \\
\text { before the classes. }\end{array}$ & 313 & 1 & 5 & 4.17 & 1.165 \\
\hline $\begin{array}{l}\text { 13. I start classes with a summary reminder of the } \\
\text { previous class. }\end{array}$ & 313 & 1 & 5 & 4.21 & 0.968 \\
\hline $\begin{array}{l}\text { 14. In the explanations I use visual aids (images, Powers, } \\
\text { diagrams...). }\end{array}$ & 313 & 1 & 5 & 4.61 & 0.779 \\
\hline $\begin{array}{l}\text { 15. Theoretical classes are of listening of the explanations } \\
\text { that I realize. }\end{array}$ & 313 & 1 & 5 & 3.62 & 1.029 \\
\hline 16. I tutor individually the work done by the students. & 313 & 1 & 5 & 3.96 & 0.964 \\
\hline $\begin{array}{l}\text { 17. I encourage students to expand and research on the } \\
\text { subject. }\end{array}$ & 313 & 1 & 5 & 4.15 & 0.840 \\
\hline $\begin{array}{l}\text { 18. In the practical classes we work in organized } \\
\text { cooperative groups. }\end{array}$ & 313 & 1 & 5 & 3.65 & 1.185 \\
\hline $\begin{array}{l}\text { 19. In the theory as well as in the practice all the students } \\
\text { use the same materials (notes and practical works). }\end{array}$ & 313 & 2 & 5 & 4.52 & 0.717 \\
\hline $\begin{array}{l}\text { 20. I use different methodological formats to adapt to the } \\
\text { learning styles of the students. }\end{array}$ & 313 & 1 & 5 & 3.23 & 1.165 \\
\hline $\begin{array}{l}\text { 21. ICTs are fundamental in the teaching of my contents } \\
\text { and in the conduct of student activities. }\end{array}$ & 313 & 1 & 5 & 3.94 & 1.048 \\
\hline
\end{tabular}

Note: $1=$ Nothing frequent. 2=Frequent. 3=Moderately frequent. 4= Fairly frequent. 5= Totally frequent.

Table 4. Mean and standard deviation of the answers given on the level of application of inclusive methodologies in university students.

As can be observed, the participating teachers apply with a higher mean (4.61) visual aids to their explanations. Also, with a mean also high of 4.52, the lecturers make their students use the same materials in both theory and practice. It should also be noted that the methodologies mentioned in items 12, 13 and 17 have mean higher than 4, and consequently are applied quite frequently. On the other hand, items 15, 16, 18, 20 and 21 are already with mean lower than 4, with item 20, I use different methodological formats to adapt myself to the learning styles of the student body, which has a lower mean (3.23).

\subsection{Difficulty in Applying Inclusive Methodologies to University Students with Disabilities}

In Table 5, we present the averages and typical deviations of the degree of agreement on the difficulty perceived by teachers in the application of inclusive methodologies in university students with disabilities.

In the results shown, it can be appreciated that with the highest mean agreement (4.21) the teaching staff considers that the students with disabilities should acquire the same competences in the degree as the rest of the classmates. Furthermore, with an average of 2.10, the majority of teachers disagree that it has been difficult for them to teach when there are students with disabilities. Items 31, 33, 37, 38, 39,41 and 43 mostly generate a degree of intermediate agreement, neither of agreement, nor in disagreement, with averages lower than four, but greater than three. Among the items with averages already lower than 2, item 42 stands out, in which the participating teachers perceive with a majority degree of disagreement that it would be difficult to adapt the contents and materials for students with disabilities. Finally, it is also worth mentioning that, with a low average of 2.28 , the teachers, in item 34, disagree that specific groups should be planned in the degrees for students with disabilities. 


\begin{tabular}{|c|c|c|c|c|c|}
\hline Items & $\mathbf{N}$ & Minimum & Maximum & Average & DT \\
\hline $\begin{array}{l}\text { 30. It is difficult for me to teach if there are students with } \\
\text { disabilities in the classroom. }\end{array}$ & 313 & 1 & 5 & 2.15 & 0.994 \\
\hline $\begin{array}{l}\text { 31. The principles of accessibility and universal design for } \\
\text { all are present in the degree I teach. }\end{array}$ & 313 & 1 & 5 & 3.08 & 1.006 \\
\hline $\begin{array}{l}32 \text { It is difficult for me to teach if I have students with a } \\
\text { sensory disability in the classroom: hearing or visual. }\end{array}$ & 313 & 1 & 5 & 2.59 & 1.181 \\
\hline $\begin{array}{l}\text { 33. The inclusion of disabled students in the university } \\
\text { depends largely on the teaching staff. }\end{array}$ & 313 & 1 & 5 & 3.21 & 1.170 \\
\hline $\begin{array}{l}\text { 34. The university should plan specific groups in the } \\
\text { degrees for students with disabilities. }\end{array}$ & 313 & 1 & 5 & 2.28 & 1.151 \\
\hline $\begin{array}{l}\text { 35. The current EHEA methodology facilitates the } \\
\text { integration of this group of students into the university. }\end{array}$ & 313 & 1 & 5 & 2.93 & 0.802 \\
\hline $\begin{array}{l}\text { 36. The competences that the disabled students must } \\
\text { acquire in the degree they take must be the same as the rest } \\
\text { of the students. }\end{array}$ & 313 & 1 & 5 & 4.21 & 0.877 \\
\hline $\begin{array}{l}\text { 37. Students with disabilities cannot follow the learning } \\
\text { rhythm of the rest of the students and need continuous } \\
\text { tutoring. }\end{array}$ & 313 & 1 & 5 & 3.03 & 1.051 \\
\hline $\begin{array}{l}\text { 38. Lack of knowledge of other communication systems, } \\
\text { other than oral, such as sign language or others hinders } \\
\text { communication with students with hearing disabilities. }\end{array}$ & 313 & 1 & 5 & 3.73 & 0.966 \\
\hline $\begin{array}{l}\text { 39. The same classmates can act as tutors for students with } \\
\text { disabilities }\end{array}$ & 313 & 1 & 5 & 3.72 & 0.927 \\
\hline $\begin{array}{l}\text { 40. It has been easier for me when I have had students } \\
\text { with disabilities in the classes, to lower the level when it } \\
\text { comes to evaluating. }\end{array}$ & 313 & 1 & 5 & 2.10 & 0.964 \\
\hline $\begin{array}{l}\text { 41. It is necessary to make the work to be done by disabled } \\
\text { students more flexible, but the evaluation must be the } \\
\text { same as the rest of the students. }\end{array}$ & 313 & 1 & 5 & 3.84 & 1.009 \\
\hline $\begin{array}{l}\text { 42. When I have had students with disabilities in the } \\
\text { classes it has been quite difficult for me to adapt the } \\
\text { contents and materials of the subject to the needs of this } \\
\text { student body. }\end{array}$ & 313 & 1 & 5 & 2.48 & 1.023 \\
\hline $\begin{array}{l}\text { 43. The faculty of the group in which the disabled student } \\
\text { body is enrolled must be coordinated. }\end{array}$ & 313 & 1 & 5 & 3.79 & 0.979 \\
\hline
\end{tabular}

Table 5. Mean and standard deviation of the answers given on the difficulty in the application of inclusive methodologies in university students

\subsection{Differences in Teaching Perceptions Regarding the Application of Inclusive Methodologies in University Students According to the Professional Category and the Branch of Knowledge of the Faculty}

In order to determine the type of test to be used for the identification and analysis of possible significant differences between the compared groups, the Kolmogorov-Smirnov and Shapiro-Wilk normality tests were carried out. The results showed that the variables of educational perceptions on the application of inclusive methodologies did not follow a criterion of normal distribution among the groups, since levels of significance less than 0.05 were obtained. Therefore, it was decided to conduct nonparametric statistical tests.

In relation to the professional category of teachers, since there are more than two levels of grouping of the variable, the Kruskal-Wallis test was used. The levels of significance obtained in each item are shown in Table 6. 


\begin{tabular}{|r|r|}
\hline Item & \multicolumn{1}{|c|}{ P-value } \\
\hline 30 & .370 \\
\hline 31 & .912 \\
\hline 32 & .285 \\
\hline 33 & $.043 *$ \\
\hline 34 & .790 \\
\hline 35 & .444 \\
\hline 36 & .659 \\
\hline 37 & .380 \\
\hline 38 & .064 \\
\hline 39 & .783 \\
\hline 40 & $.031 *$ \\
\hline 41 & .705 \\
\hline 42 & .233 \\
\hline 43 & .205 \\
\hline
\end{tabular}

Table 6. Significant differences among the items according to the professional category of the faculty

As can be seen from the results of the Kruskal-Wallis test, items 33 and 40 have significant differences according to the professional category, as their significance levels are less than 0.05 . To complete the information on these significant differences, the average ranges are presented below (Table 7).

\begin{tabular}{|c|c|c|c|}
\hline Items & Professional category & $\mathbf{N}$ & Average range \\
\hline \multirow{9}{*}{$\begin{array}{l}\text { 33. The inclusion of } \\
\text { disabled students at } \\
\text { university depends } \\
\text { largely on the teaching } \\
\text { staff. }\end{array}$} & Full Professor & 39 & 156.42 \\
\hline & Senior Lecturer & 96 & 152.83 \\
\hline & University School Professor & 4 & 36.25 \\
\hline & University School Holder & 31 & 150.73 \\
\hline & Lecturer & 17 & 134.29 \\
\hline & Assistant doctor & 18 & 190.00 \\
\hline & Tutor & 16 & 187.78 \\
\hline & Others (scholarship holders, teaching fellow, collaborators) & 92 & 149.39 \\
\hline & Total & 313 & \\
\hline \multirow{9}{*}{$\begin{array}{l}\text { 40. It has been easier } \\
\text { for me when I have had } \\
\text { students with } \\
\text { disabilities in the } \\
\text { classes, to lower the } \\
\text { level when it comes to } \\
\text { evaluating. }\end{array}$} & Full Professor & 39 & 183.72 \\
\hline & Senior Lecturer & 96 & 143.64 \\
\hline & University School Professor & 4 & 121.88 \\
\hline & University School Holder & 31 & 139.16 \\
\hline & Lecturer & 17 & 108.50 \\
\hline & Assistant doctor & 18 & 139.86 \\
\hline & Tutor & 16 & $161 . .47$ \\
\hline & Others (scholarship holders, teaching fellow, collaborators) & 92 & 165.87 \\
\hline & Total & 313 & \\
\hline
\end{tabular}

Table 7. Average ranks of the items with significant differences according to the professional category of the faculty

From the results shown, it can be seen that in item 33, the assistant doctor and tutor perceive with a higher average (190.00 and 187.78) that the inclusion of the student body depends on the figure of the professor in comparison with other professional categories, especially with university school professors or scholarship holders, associates and collaborators. On the other hand, in item 40, it is observed that full professors perceive with a higher average (183.72) the ease of lowering the level when evaluating students with disabilities in comparison with lecturers or university school professors. 
The Kruskal-Wallis test was also conducted with respect to the branch of knowledge of the faculty, giving the results of significance presented in Table 8.

\begin{tabular}{|r|r|}
\hline Item & \multicolumn{1}{|c|}{ P-value } \\
\hline 30 & .076 \\
\hline 31 & $.021^{*}$ \\
\hline 32 & $.005^{*}$ \\
\hline 33 & .078 \\
\hline 34 & $.032^{*}$ \\
\hline 35 & .386 \\
\hline 36 & .143 \\
\hline 37 & .440 \\
\hline 38 & .657 \\
\hline 39 & .438 \\
\hline 40 & .203 \\
\hline 41 & .606 \\
\hline 42 & $.015^{*}$ \\
\hline 43 & .159 \\
\hline
\end{tabular}

Table 8. Significant differences in the items according to the branch of knowledge of the faculty

As can be seen in the data presented, there are significant differences in four items (31, 32, 34 and 42). The following table (Table 9) shows how these differences are expressed in the groups compared from the respective average ranges.

\begin{tabular}{|c|c|c|c|}
\hline Items & Field of knowledge & $\mathbf{N}$ & Average range \\
\hline \multirow{6}{*}{$\begin{array}{l}\text { 31. The principles of accessibility } \\
\text { and universal design for all are } \\
\text { present in the degree that I teach }\end{array}$} & Humanities & 61 & 151.08 \\
\hline & Health Sciences & 16 & 187.31 \\
\hline & Social and Legal Sciences & 122 & 151.39 \\
\hline & Experimental Sciences & 37 & 119.39 \\
\hline & Engineering and Technology & 77 & 168.36 \\
\hline & Total & 313 & \\
\hline \multirow{6}{*}{$\begin{array}{l}\text { 32. It is difficult for me to teach if I } \\
\text { have students with a sensory } \\
\text { disability in the classroom: hearing } \\
\text { or visual. }\end{array}$} & Humanities & 61 & 145.94 \\
\hline & Health Sciences & 16 & 106.13 \\
\hline & Social and Legal Sciences & 122 & 142.59 \\
\hline & Experimental Sciences & 37 & 173.91 \\
\hline & Engineering and Technology & 77 & 176.79 \\
\hline & Total & 313 & \\
\hline \multirow{6}{*}{$\begin{array}{l}\text { 34. The university should plan } \\
\text { specific groups in the degrees for } \\
\text { students with disabilities }\end{array}$} & Humanities & 61 & 160.82 \\
\hline & Health Sciences & 16 & 164.75 \\
\hline & Social and Legal Sciences & 122 & 137.50 \\
\hline & Experimental Sciences & 37 & 143.20 \\
\hline & Engineering and Technology & 77 & 175.80 \\
\hline & Total & 313 & \\
\hline \multirow{6}{*}{$\begin{array}{l}\text { 42. When I have had students with } \\
\text { disabilities in the classes it has been } \\
\text { quite difficult for me to modify the } \\
\text { contents and materials of the subject } \\
\text { to the needs of this student body. }\end{array}$} & Humanities & 61 & 179.08 \\
\hline & Health Sciences & 16 & 132.87 \\
\hline & Social and Legal Sciences & 122 & 137.85 \\
\hline & Experimental Sciences & 37 & 171.32 \\
\hline & Engineering and Technology & 77 & 151.51 \\
\hline & Total & 313 & \\
\hline
\end{tabular}

Table 9. Average ranks of items with significant differences according to the branch of knowledge of the teaching faculty 
As can be observed in the results presented in the previous table, in item 31, the health sciences faculty perceives with a higher average rank (187.31) that the principles of accessibility and universal design are present in the degree in comparison to the faculty of the other branches of knowledge, especially that of experimental sciences (119.39). For their part, the Engineering and Technology and Experimental Sciences faculties perceive with a higher average rank the difficulty of teaching with students with sensory disabilities. Likewise, the Engineering and Technology faculty with a higher first rank (175.80) perceives that the university should plan specific groups for students with disabilities. Finally, as can be observed, in item 42, the faculty of Humanities and Experimental Sciences (179.08 and 171.32) have higher average ranks than the rest of the faculty.

\section{Discussions}

The main objective of this research was to analyze the application of inclusive methodologies in university students with disabilities from a teaching approach. In this sense, the first section of the questionnaire focuses on the application of inclusive methodologies. It is important to emphasize the ratings obtained in item 14 and item 20. In addition to this, Item 14 analyses the use of visual aids and scores 4.61. In contrast, in item 20 the score is 3.23. Moreover, this item focuses on the use of different methodological formats for adaptation to the students' learning styles These results are in line with those obtained by Mather and Muchatuta (2011), Guasch and Hernández (2012), Mullins and Preyde (2013), Liasidou (2014), Strnadová, Hájková and Květoňová (2015) and Burgstahler (2015), which note that teachers are gradually tending to create more flexible learning scenarios in the classroom based on the methodologies and teaching resources used. This finding is reinforced by the frequency in which cooperative groups are created, as shown in item 18, with an average of 3.65. Therefore, it suggests a trend towards the application of universal design, as already seen in their research Gradel and Edson (2010) and Lledó, Lorenzo-Lledó and Lorenzo (2018).

The second section of the questionnaire is centered on teachers' perceptions of the difficulties encountered in the application of inclusive methodologies. Significant results have been obtained in items 31, 33, 38. Item 31 studies the problem of accessibility and Universal design, obtaining a score of 3.08. As for item 33 which focuses on the dependence of the inclusion of the students on the teaching staff, it achieves a score of 3.21. Finally, item 38 received a score of 3.73 and dealt with the lack of knowledge of the teacher about alternative communication systems. These are some of the barriers detected and which are in line with those found in the research of Hong, Haefner and Slekar (2011), Hopkins (2011), Moswela and Mukhopadhyay (2011), Mullins and Preyde (2013), Moriña et al. (2015) and Nuñez (2017). In addition to this, these authors explain other difficulties such as the assistance provided by universities, the unobtainable curriculums, the negative attitudes of the teaching staff or the architectural barriers. In this sense, item 34, 42 referring to the ease of adapting materials for students with disability and the nonconvenience of planning for specific groups, values close to 2 are obtained. As a consequence, it is pointed out that teachers are aware that the use of inclusive methodologies can generate improvements in students with disabilities, as already stated by Schreuer and Sachs (2014).

Likewise, the third section focused on the differences in teaching perceptions about the application of inclusive methodologies shows some noteworthy results. For example, teachers with lower professional categories (PHD students...) obtain higher average ranges (190.00 and 187.78) compared to the higher professional categories (Full Professor...). This result can be said to be due to the fact that, as indicated by Hellmich and Görel (2014) and Urton, Wilbert and Hennemann (2014), this younger group has had more contact with a more innovative and inclusive methodological model. As a result, they are more sensitive, aware, and predisposed to the application of inclusive methodologies.

Regarding the influence of the field of knowledge, the Health Sciences present a high average range (187.00) in item 34. Moreover, it is regarding the need to create groups only for students with disabilities. This finding is reinforced by the research of Rao (2004), Gonçalves and Cardoso (2010), Sachs \& Schreuer (2011), which show the great influence that the medical model has on our society. Therefore, this 
model established what is normal or outside the norm. For this reason, in Health Science there is a greater tendency towards a traditional perception of disability.

\section{Conclusions}

Based on the results obtained in the study, and trying to respond to the proposed objectives, it is important to mention the following conclusions:

As regards the degree of application of inclusive methodologies in university students with disabilities, teachers apply visual aids more frequently in their explanations, which is very beneficial for students with a sensory auditory disability, but a disadvantage for students with a sensory visual disability. Nonetheless, the use of different strategies such as the review of previously studied contents or the provision of materials before classes facilitates adapting the teaching process to the different learning rhythms. As weaknesses, it should be noted that teachers apply less frequently cooperative group work, individual tutoring and different methodological training, which can make university curricula more flexible. This finding is in line with that of Melero, Moriña and Perera (2019), which show the lack of teacher training for the use of methodologies in a classroom with a diversity of learning styles.

Concerning perceptions of the difficulty perceived by teachers in applying inclusive methodologies, teachers have a positive perception of inclusion, considering that students with disabilities should acquire the same skills as other classmates and that specific groups should not be created for students with disabilities. This reflects the fact that the educational paradigm of segregation has been overcome in the mentality of teachers. In addition, it was not difficult for them to teach classes with students with disabilities or to adapt the contents and materials. Nevertheless, it is considered necessary to make the work of this student body more flexible and to carry out continuous tutoring to support their learning, understanding the role of the teacher as fundamental, even if there is no perception that the EHEA methodologies are facilitating inclusion.

As regards differences in perceptions, there are significant differences depending on the professional category of the teaching staff and the branch of knowledge. In this sense, non-doctoral assistants and doctors perceive highly that the figure of the teacher is important in the inclusion of students with disabilities, and university professors, in accordance with their greater experience and preparation, perceive it easier to lower the level when evaluating students with disabilities.

Continuing with the significant differences, it should be noted that the teaching staff of Health Sciences perceives more that in their degree they present the principles of accessibility and universal design as opposed to the teachers of Experimental Sciences. At the same time, as well as the Engineering and Technology teaching staff, it is more difficult for them to teach with students with a sensory disability. Similarly, the Engineering and Technology faculty is more in favor of planning specific groups in the degrees for students with disabilities, which contrasts with the usefulness of technological resources to facilitate learning for students with disabilities. On the other hand, Humanities teachers perceive significantly more difficulties in modifying the contents and materials of the subjects, a fact that can be determined by a more textual and encyclopedic type of training.

In the center where the research has been conducted, the University of Alicante, in recent years the 2015 Curricular Adaptation Regulation has been promoted, which obliges teachers to carry out curricular adaptations as an educational strategy that allows students access to and promotion of the ordinary curriculum while at the same time guaranteeing the acquisition of the professional skills and academic content established by university degrees that enable them to practice professionally. This is evidenced by the findings of this study, which already show changes that can be considered as significant, even though we must continue working for educational inclusion. In this sense, research on this subject is a commitment to achieving a modern university of educational excellence and this is not possible without guaranteeing the presence, participation and academic achievements in equal opportunities of all students, especially those with some type of disability. It is therefore appropriate to take advantage of these studies 
as a source for the improvement of teaching practice and the quality of education that facilitates the conditions for the academic performance of people with disabilities in Spanish universities.

\section{Declaration of Conflicting Interests}

The authors declared no potential conflicts of interest with respect to the research, authorship, and/or publication of this article.

\section{Funding}

The authors received no financial support for the research, authorship, and/or publication of this article.

\section{References}

Albert, M.J. (2007). La investigación educativa. Claves teóricas. Madrid: McGraw Hill.

Alper, S., \& Ryndak, D.L. (1992). Educating students with severe handicaps in regular classes. The Elementary School Journal, 92(3), 373-387. https://doi.org/10.1086/461698

Barroso, J., \& Cabero, J. (2010). La investigación educativa en TIC. Visiones prácticas. Madrid: Síntesis.

Bisquerra, R. (2014). Metodología de la investigación educativa. Madrid: La Muralla.

Booth, T. (2006). Manteniendo el futuro con vida: convirtiendo los valores de la inclusión en acciones. In Verdugo, M.A., \& Jordán de Urríes, F-B. (Coords.), Rompiendo inercias. Claves para avanzar. VI Jornadas Cientificas de Investigación sobre Personas con Discapacidad (211-217). Salamanca: Amarú.

Borland, J., \& James, S. (1999) The learning experience of students with disabilities in higher education. Disability \& Society, 14 (1), 85 101. https://doi.org/10.1080/09687599926398

Burgstahler, S. (2015). Opening doors or slamming them shut? Online learning practices and students with disabilities. Social Inclusion, 3(6), 69-79. https://doi.org/10.17645/si.v3i6.420

Castellana, M., \& Sala, I. (2006). La inclusión de los estudiantes con discapacidad en la universidad: Un reto para la universidad española en el nuevo espacio europeo de la educación superior. Revista Aloma, $18,209-229$

Cohen, L., \& Manion, L. (1990). Métodos de investigación educativa. Madrid: La Muralla.

Díaz, V., \& Funes, S. (2016). Universidad inclusiva: reflexiones a partir de las experiencias de estudiantes con discapacidad de una universidad pública madrileña. Prisma Social, 16 (1), 450-494.

Díez, E., \& Sánchez, S. (2015). Diseño universal para el aprendizaje como metodología docente para atender a la diversidad en la universidad. Aula Abierta, 43(1), 87-93.

https://doi.org/10.1016/j.aula.2014.12.002

George, D., \& Mallery, P. (2003). SPSS for Windows step by step: A simple guide and reference. 11.0 update (4th ed.). Boston: Allyn \& Bacon.

Gonçalvez, I., \& Cardoso, P. (2010). Perception of Career Barriers: Study with University Students with Disabilities. International Journal of Developmental and Educational Psychology, 1(4), 495-503.

González-Cortés, E., \& Roses-Campos, S. (2016). ¿Barreras invisibles? Actitudes de los estudiantes universitarios ante sus compañeros con discapacidad. Revista Complutense de Educación, 27(1), 219-235. https://doi.org/10.5209/rev_RCED.2016.v27.n1.45702

Gradel, K., \& Edson, A.J. (2010). Putting universal design for learning on the higher ed agenda. Journal of Educational Technology Systems, 38(1), 111-121. https://doi.org/10.2190/ET.38.2.d 
Guasch, D., \& Hernández (2012) (Coord.). Guia para implementar el Universal Instructional Design — UID (diseño instruccional universal en la universidad). Barcelona: Observatorio Universidad y Discapacidad.

Guskey, T.R. (2013). Defining student achievement. In Hattie, J., \& Anderman, E.M. (Eds.), International Guide to Student Achievement (3-7). Nueva York: Routledge.

Hattie, J., \& Anderman, E.M. (2012). International Guide to Student Achievement. Routledge: New York. https://doi.org/10.4324/9780203850398

Hellmich, F., \& Görel, G. (2014). Erklärungsfaktoren für Einstellungen von Lehrerinnen und Lehrern zum inklusiven Unterricht in der Grundschule. Zeitschrift für Bildungsforschung, 4(3), 227-240. https://doi.org/10.1007/s35834-014-0102-z

Hong, B.S.S., Haefner, L. \& Slekar, T. (2011). Faculty attitudes and knowledge toward promoting selfdetermination and self-directed learning for college students with and without disabilities. International Journal of Teaching and Learning in Higher Education, 23(1), 175-185.

Hopkins, L. (2011). The path of least resistance: A voice-relational analysis of disabled students' experiences of discrimination in English universities. International Journal of Inclusive Education, 15 (1), 711-727. https://doi.org/10.1080/13603110903317684

Latorre A., Del Rincón, D., \& Arnal, J. (2005). Bases metodológicas de la investigación educativa. Barcelona: Ediciones Experiencia.

Lawshe, C.H. (1975). A quantitative approach to content validity. Personnel Psychology, 28(4), 563-575. https://doi.org/10.1111/j.1744-6570.1975.tb01393.x

León, O., \& Montero, I. (2002). Métodos de investigación en Psicología y Educación. Madrid: McGraw-Hill.

Liasidou, A. (2014). Critical disability studies and socially just change in higher education. British Journal of Special Education, 41(1), 120-135. https://doi.org/10.1111/1467-8578.12063

Lledó, A., Lorenzo-Lledó, A., \& Lorenzo, G. (2018). Metodologías inclusivas percibidas por el alumnado del Grado de Maestro desde el diseño universal para el aprendizaje. In: Roig-Vila, R. (Ed.), El compromiso académico y social a través de la investigación e innovación educativas en la Enseñanza Superior (978-984). Barcelona: Octaedro.

Marcelo, C., \& Yot, C. (2010). Diseños del aprendizaje y enseñanza universitaria. Patrones de secuencias de tareas de aprendizaje. VI Congreso Iberoamericano de Docencia Universitaria. Lima (Perú): Asociación Iberoamericana de Didáctica Universitari.

Martin, S.N \& Kang, D.Y. (2018). Improving learning opportunities for special education needs (SEN) students by engaging pre-service science teachers in an informal experiential learning course. Asia Pacific Journal of Education, 38(3), 319-347.

Mather, G., \& Muchatuta, M. (2011). How to teach with inclusive practice. Learning through diversity. Sydney: Macquarie University.

Melero, N., Moriña, A., \& Perera, V. (2019). Acciones del profesorado para una práctica inclusiva en la universidad. Revista Brasileira de Educasao, 24(1), 1-19. https://doi.org/10.1590/s1413-24782019240016

Morgan, P.L., Farkas, G., \& Wu, Q. (2011). Jinggarthen children's growth trajectories in reading and mathematics: Who falls increasingly behind? Journal of Learning Disabilities, 44(5), 472-488.

https://doi.org/10.1177/0022219411414010

Moriña-Diez, A., López, R., Melero, N., Cortés, M.D., \& Molina, V. (2013). El profesorado en la universidad ante el alumnado con discapacidad ¿'Tendiendo puentes o levantando muros? Revista de docencia universitaria, 11(3), 423-442. https://doi.org/10.4995/redu.2013.5537 
Moriña, A., Cortés, M. D., \& Molina, V. M. (2015). What if we could imagine the ideal faculty? Proposals for improvement by university students with disabilities. Teacbing and Teacher Education, 52, 91-98. https://doi.org/10.1016/j.tate.2015.09.008

Moriña, A. (2019). The keys to learning for university students with disabilities: Motivation, emotion and faculty-student relationships. PLoS ONE, 14(5), 1-15. https://doi.org/10.1371/journal.pone.0215249

Moswela, E., \& Mukhopadhyay, S. (2011). Asking for too much? The voices of students with disabilities in Botswana. Disability \& Society, 26(1), 307-319. https://doi.org/10.1080/09687599.2011.560414

Mullins, L. \& Preyde, M. (2013). The lived experience of students with an invisible disability at a Canadian university. Disability \& Society, 28(2), 147-160. https://doi.org/10.1080/09687599.2012.752127

Nelson, J.R., Benner, G.J., Lane, K., \& Smith, B.W. (2004). Academic achievement of K-12 students with emotional and behavioral disorders. Exceptional Children, 71(1), 59-73. https://doi.org/10.1177/001440290407100104

Núñez, M.T. (2017). Estudiantes con discapacidad e inclusión educativa en la Universidad: Avances y retos para el futuro. Revista Nacional e Internacional de Educación Inclusiva, 10(1), 13-30.

Rao, S. (2004). Faculty Attitudes and Students with Disabilities in Higher Education: A Literature Review. College Student Journal, 38(2), 191-198.

Sachs, D., \& Schreuer, N. (2011). Inclusion of students with Disabilities in Higher Education: Performance and participation in Student's experiences. Disability Studies Quarterly, 31(2), 99-106. https://doi.org/10.18061/dsq.v31i2.1593

Sánchez, M. (1994). Inventario de creencias de supervisor (I.C.S.): Un instrumento para estudiar los diferentes estilos de supervisión. Enseñanza, XII, 1(1) 109-137.

Sandoval, M., Simón, C., \& Márquez, C. (2019). ¿Aulas inclusivas o excluyentes?: barreras para el aprendizaje y la participación en contextos universitarios. Revista Complutense de Educación, 30(1), 261-276. https://doi.org/10.5209/RCED.57266

Schreuer, N., \& Sachs, D. (2014). Efficacy of accommodations for students with disabilities in higher education. Journal of Vocational Rehabilitation, Netherlands, 40(1), 27-40. https://doi.org/10.3233/JVR-130665

Scruggs, T.E., \& Mastropieri, M.A. (2004). Recent research in secondary content areas for students with learning and behavior disabilities. In Scruggs, T.E., \& Mastropieri, M.A. (Eds.), Research in secondary schools: Advances in learning and behavioral disabilities (17, 243-263). Oxford, UK: Elsevier Science. https://doi.org/10.1016/S0735-004X(04)17010-9

Scruggs, T.E., \& Mastropieri, M.A. (1996). Teacher perceptions of mainstreaming/inclusion, 1958-1995: A research synthesis. Exceptional Children, 63(1), 59-74. https://doi.org/10.1177/001440299606300106

Strnadová, I., Hájková, V., \& Květoňová, L. (2015). Voices of university students with disabilities: inclusive education on the tertiary level - a reality or a distant dream? International Journal of Inclusive Education, 19(10), 1080-1095. https://doi.org/10.1080/13603116.2015.1037868

Thomas, L. (2016). Developing inclusive learning to improve the engagement, belonging, retention, and success of students from diverse groups. In Shah, M., Bennett, A., \& Southgate, E. (Eds.), Widening higher education participation. A global perspective (135-159). Oxford: Elsevier. https://doi.org/10.1016/B978-008-100213-1.00009-3

UNESCO (1998). Declaración Mundial sobre la Educación Superior en el siglo XXI: visión y acción. Available at: http://www.unesco.org/education/educprog/wche/declaration spa.htm 
Urton, K., Wilbert, J., \& Hennemann, T. (2014). Attitudes towards Inclusion and Self-Efficacy of Principals and Teachers. Learning Disabilities: A Contemporary Journal, 12(2), 151-168.

Published by OmniaScience (www.omniascience.com)

Journal of Technology and Science Education, 2020 (www.jotse.org)

\section{(c) (1) (8)}

Article's contents are provided on an Attribution-Non Commercial 4.0 Creative commons International License. Readers are allowed to copy, distribute and communicate article's contents, provided the author's and JOTSE journal's names are included. It must not be used for commercial purposes. To see the complete licence contents, please visit https://creativecommons.org/licenses/by-nc/4.0/. 